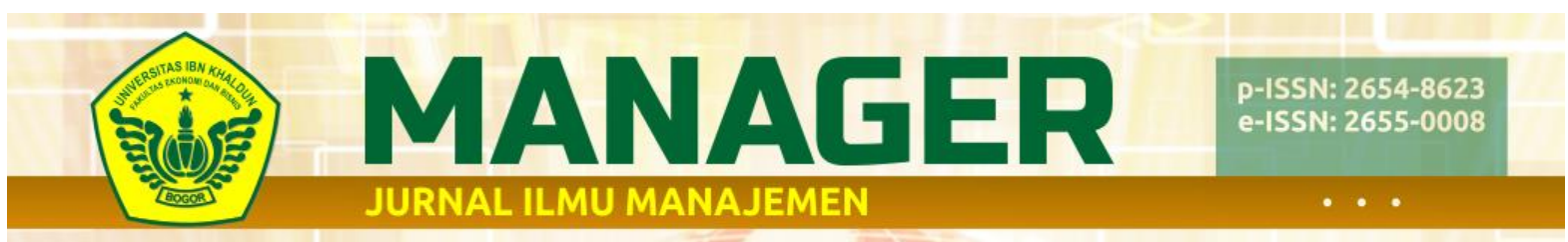

Vol. 3, No. 2, Mei 2020, Hal. 225-236

\title{
PENGARUH PELATIHAN DAN DISIPLIN KERJA TERHADAP KUALITAS KERJA
}

\author{
Yogi Supriatna, M. Azis Firdaus, Rachmatulaily Tinakartika Rinda \\ Fakultas Ekonomi dan Bisnis Universitas Ibn Khaldun Bogor, Indonesia \\ Yogisupriatna00@gmail.com, azisfirdaus@uika-bogor.ac.id, \\ lailyrinda@yahoo.com
}

\begin{abstract}
This study entitled the influence of Job Training and Work Discipline on Work Quality Aperatur Sipil Negara at Kantor Badan Pertanahan Nasional Kota Bogor. This study aims to determine the extent of "The influence of Job Training and Work Discipline on Work Quality Aperatur Sipil Negara Kota Bogor". Date collection used survey methods using primary data through questionnaires. In this study the total sample population used was 41 people. The result of data analysis using computer application the result is $r=0,762$. These results indicate that there are positive influence between variables X1 (Job Training) to variable $Y$ (Work Quality Aperatur Sipil Negara). the result is $r=0,533$. These results indicate that there are positive influence between variables X2 (Work Discipline) to variable $Y$ (Work Quality Aperatur Sipil Negara). the result is $r=0,762$. These results indicate that there are positive influence between variables X1 (Job Training) and X2 (Work Discipline) to variable $Y$ (Work Quality Aperatur Sipil Negara). Analysis using the F test, shows the calculated $F$ is $F=9,280>F$ table $=3,24$, then Ho is rejected (Ha acceptable), means there were a significant which shows the existence of significant influence between Job Training and Work Discipline to Work Quality Aperatur Sipil Negara. From the explanation above, the writer recommends to maintain existing ones and improve the quality of existing work, all training and work discipline so that it can run well and can provide better performance results.
\end{abstract}

Keywords : Job Training, Work Discipline, Work Quality.

\begin{abstract}
Abstrak
Penelitian ini berjudul Pengaruh Pelatihan dan Disiplin Kerja terhadap Kualitas Kerja Aperatur Sipil Negara di Kantor Badan Pertanahan Nasional Kota Bogor. Penelitian ini bertujuan untuk mengetahui sejauh mana "Pengaruh Pelatihan dan Disiplin Kerja terhadap Kualitas Kerja Aperatur Sipil Negara Kota Bogor". Pengumpulan data menggunakan metode survei dengan menggunakan data primer melalui penyebaran kuesioner. Dalam penelitian ini jumlah populasi sampel yang digunakan sebanyak 41 orang. Hasil analisis data menggunakan aplikasi komputer dengan hasil $r=0,762$. Hasil ini menunjukan bahwa terdapat hubungan yang kuat dan positif antara Variabel $\mathrm{X}_{1}$ (Pelatihan) terhadap variabel Y (Kualitas). Hasil $\mathrm{r}=$ 0,533, hasil ini menunjukan bahwa terdapat hubungan yang sedang dan positif antara Variabel X2 (Disiplin Kerja) terhadap Variabel Y (Kualitas). Hasil $r=0,762$ hasil ini menunjukan bahwa terdapat hubungan yang kuat dan positif antara variabel X1 (Pelatihan)
\end{abstract}


dan X2 (Disiplin Kerja) Terhadap Y (Kualitas Kerja). Analisis menggunakan uji F, menunjukan $\mathrm{F}$ hitung $=9,280>\mathrm{F}$ tabel $=3,24$, maka Ho ditolak (Ha diterima), berarti terdapat pengaruh yang signifikan yang menunjukan adanya pengaruh yang signifikan antara Pelatihan dan Disiplin Kerja terhadap Kualitas kerja. Dari penjelasan diatas penulis menyarankan untuk mempertahankan yang telah ada dan meningkatkan kualitas kerja yang ada, segala Pelatihan dan disiplin kerja agar dapat berjalan dengan baik dan dapat memberikan hasil kinerja yang lebih baik.

\section{Kata Kunci : Pelatihan, Disiplin Kerja dan Kualitas Kerja}

\section{Pendahuluan}

\section{Latar Belakang Penelitian}

Perusahaan sangat membutuhkan sumber daya manusia yang kompoten dan berkualitas, terutama di era globalisasi ini. Semua organisasi bisnis harus siap beradaptasi dan memperkuat diri agar dapat bersaing sehingga mampu menjawab semua tantangan di masa yang akan datang. Sumber daya manusia dalam hal ini adalah Aparatur Sipil Negara yang selalu berperan aktif dan dominan dalam setiap kegiatan organisasi karena manusia sebagai perencana, pelaku serta penentu terwujudnya tujuan organisasi.

Dilihat dari sudut manajemen, baik dalam ruang lingkup pemerintahan organisasi maupun swasta, manusia menempati posisi utama diantara sumbersumber daya lainnya, sumber daya manusia dalam sebuah organisasi akan berperan secara efektif bila dikendalikan oleh para tenaga kerja yang mempunyai kualitas kerja yang baik. Perencanaan dan pemanfaatan sumber daya manusia yang tepat akan sangat mempermudah dalam upaya meningkatkan efesiensi dan efektifitas.

Setiap perusahaan yang telah didirikan pasti mempunyai harapan bahwa kelak dikemudian hari akan mengalami perkembangan yang pesat di dalam suatu usaha dalam perusahaan tersebut. Pada setiap perusahaan menghendaki adanya keuntungan yang maksimal, dalam mencapai hasil yang maksimal perusahaan itu diperlukan kualitas yang tinggi, dengan demikian kelangsungan perusahaan dapat terjamin dan dapat mengembangkan usaha - usahanya.

Pelatihan bagi Aparatur Sipil Negara merupakan sebuah proses mengajarkan pengetahuan dan keahlian tertentu serta sikap agar Aparatur Sipil Negara semakin terampil dan mampu melaksanakan tanggung jawabnya untuk semakin baik, sesuai dengan kapasitasnya masing masing.

Fenomena saat ini yang terjadi bahwa setiap Aparatur Sipil Negara harus diberikan program pelatihan untuk mendapatkan pengetahuan dan keterampilan yang mereka butuhkan, sehingga perilaku, disiplin, dan kemampuan serta keterampilan mereka dimanfaatkan untuk dapat meningkatkan kualitas kerja.

Memang di satu sisi program pelatihan Aparatur Sipil Negara memerlukan biaya dan waktu, akan tetapi di sisi lain pelatihan tersebut membuat Aparatur Sipil Negara semakin menguasai bidangnya. Peran pelatihan yaitu bahwa fungsi pelatihan yang diharapkan dapat berjalan dengan baik, jika pelatihan menjalankan perannya dengan baik maka akan mendapatkan citra yang baik di dalam memberikan pengetahuan dan keterampilan Aparatur Sipil Negara.

Setiap orang memiliki kemampuan masing-masing, dengan adanya perbedaan 
tersebut maka tenaga kerja harus mampu memahami dan menjalankan tugas secara professional agar kualitas sumber daya manusia yang lulus dari pelatihan dapat lebih baik dari sebelumnya. Metode tersebut dapat membantu dalam upaya peningkatan kualitas dari individu.

Selain pelatihan, maka hal penting yang harus diperhatikan adalah disiplin kerja. Menurut Putra dalam buku Mangkunegara (2015:244) mengemukakan bahwa disiplin kerja adalah ketaatan dalam melaksanakan aturan-aturan yang ditentukan atau diharapkan oleh organisasi atau perusahaan dalam bekerja, dengan maksud agar tenaga kerja melaksanakan tugasnya dengan baik dan lancar, termasuk penahanan diri untuk tidak melakukan perbuatan yang menyimpang dari peraturan.

Inovator, Edisi (2014) Oleh Muhamad, Undang Suryana dan M. Azis Firdaus, Pengetahuan Yang Didapat Dari Pelatihan Akan Meningkatkan Produktivitas Kerja Karyawan Tersebut. Kata Kunci: Pelatihan Dan Produktivitas Kerja.

Dengan adanya disiplin kerja yang baik, maka pelayanan terhadap pelanggan bisa dimaksimalkan, misalnya dari segi kualitas kerja, tanggung jawab serta disiplin kerja yang kurang. Jika seorang Aparatur Sipil Negara tidak memiliki yang namanya disiplin kerja maka hal tersebut nantinya dapat berdampak kurang baik bagi perusahaan seperti buruknya kinerja Aparatur Sipil Negara dalam kualitas kerja Aparatur Sipil Negara pada sebuah perusahaan merupakan masalah yang selalu hangat dan tidak ada habis-habisnya untuk diperbincangkan. Permasalahan yang terkait dalam kualitas juga merupakan isu strategis bagi perusahaan yang memprogram masalah sumber daya manusia. Banyak aspek intenal dan eksternal yang mendukung terciptanya kualitas kerja yang efektif dan efisien dalam suatu perusahaan. Apalagi bila dikaitkan dengan masalah globalisasi yang ada pada saat ini yang dampaknya sangat kita rasakan.

Kualitas kerja Aparatur Sipil Negara sangat mempengaruhi prestasinya didalam sebuah perusahaan, yang dimana hal inilah yang menjadi pertimbangan seorang atasan atau manajer dalam memberikan penilaian. Kualitas kerja yang dimaksud adalah dimana saat melakukan proses kegiatan kerja, seorang Aparatur Sipil Negara mampu menunjukan kualitas SDM yang dimilikinya dengan memberikan kontribusi yang maksimal terhadap perusahaan tempat ia bekerja.

Seorang pemimpin atau manajer dalam sebuah perusahaan mempunyai tanggung jawab untuk meyakinkan anggotanya akan perlunya ditumbuhkan, dikembangkan dan dipraktekkan hubungan kerja sama yang baik antara anggota organisasi sehingga akan mendorong anggota untuk bekerja sama dengan produktif dan dengan perasaan puas.

\section{Rumusan Masalah}

Berdasarkan uraian dari latar belakang tersebut maka permasalahan yang timbul dalam penelitian ini adalah sebagai berikut:

1. Bagaimanakah pengaruh pelatihan terhadap kualitas kerja Aparatur Sipil Negara di Kantor Badan Pertanahan Nasional (BPN) Kota Bogor?

2. Bagaimanakah bentuk pengaruh disiplin kerja terhadap kualitas kerja Aparatur Sipil Negara di Kantor Badan Pertanahan Nasional (BPN) Kota Bogor? 
3. Seberapa besar pengaruh pelatihan dan disiplin kerja terhadap kualitas kerja Aparatur Sipil Negara pada Kantor Badan Pertanahan Nasional (BPN) Kota Bogor?

\section{Tujuan Penelitian}

Penelitian ini dimaksudkan untuk memperoleh informasi yang diperlukan untuk pembahasan masalah yang ada diatas, serta untuk mengetahui bagaimana proses pelatihan dan disiplin kerja terhadap kualitas kerja karyawan. Penelitian ini dilaksanakan dengan tujuan antara lain sebagai berikut:

1. Untuk mengetahui seberapa besar pengaruh pelatihan di Kantor
Badan Pertanahan Nasional (BPN) Kota Bogor.

2. Untuk mengetahui seberapa besar pengaruh disiplin kerja dan dampaknya terhadap kualitas kerja Aparatur Sipil Negara di Kantor Badan Pertanahan Nasional (BPN) Kota Bogor.

3. Untuk mengetahui seberapa besar pengaruh pelatihan dan disiplin kerja terhadap kualitas kerja Aparatur Sipil Negara di Kantor Badan Pertanahan Nasional (BPN) Kota Bogor.

\section{Hasil dan Pembahasan}

Tabel 1

$\begin{array}{lllll}\text { Hasil } & \text { Butir } & \text { Nilai r Hitung } & \text { Nilai r Tabel } & \text { Keterangan }\end{array}$ Uji
Kuesioner

Validitas Terhadap Variabel Pelatihan (X1) pada Kantor BPN kota Bogor

\begin{tabular}{cccc}
\hline Butir Kuesioner & Nilai r Hitung & Nilai r Tabel & Keterangan \\
\hline $\mathrm{X} 1.1$ & 0,414 & 0.301 & Valid \\
\hline $\mathrm{X} 1.2$ & 0,764 & 0.301 & Valid \\
\hline $\mathrm{X} 1.3$ & 0,379 & 0.301 & Valid \\
\hline $\mathrm{X} 1.4$ & 0,395 & 0.301 & Valid \\
\hline $\mathrm{X} 1.5$ & 0,485 & 0.301 & Valid \\
\hline $\mathrm{X} 1.6$ & 0,586 & 0.301 & Valid \\
\hline $\mathrm{X} 1.7$ & 0,402 & 0.301 & Valid \\
\hline $\mathrm{X} 1.8$ & 0,457 & 0.301 & Valid \\
\hline $\mathrm{X} 1.9$ & 0,434 & 0.301 & Valid \\
\hline $\mathrm{X} 1.10$ & 0,764 & 0.301 & Valid
\end{tabular}

Berdasarkan tabel diatas dapat disandingkan pada kolom $r$ hitung (Corrected Item-Total Correlation) dengan $r$ tabel dapat dilihat dari pengujian validitas bahwa 10 item variabel penelitian penilaian Pelatihan mempunyai $\mathrm{r}$ hitung < $\mathrm{r}$ tabel yaitu pada signifikan $5 \%(\mathrm{a}=0,05)$ dan $n=41$ diperoleh $r_{\text {tabel }}=0,301$, Nilai Korelasi terbesar adalah pada pertanyaan 2 $\begin{array}{lllll}\text { dan } & 10 & \text { dengan nilai } & \mathrm{r} & 0,764\end{array}$

Tabel 2

Hasil Uji Validitas Terhadap Variabel Disiplin Kerja (X2) pada Kantor BPN kota
Bogor 


\begin{tabular}{llll}
\hline X2.1 & 0,461 & 0.301 & Valid \\
\hline X2.2 & 0,661 & 0.301 & Valid \\
\hline X2.3 & 0,452 & 0.301 & Valid \\
\hline X2.4 & 0,537 & 0.301 & Valid \\
\hline X2.5 & 0,537 & 0.301 & Valid \\
\hline X2.6 & 0,442 & 0.301 & Valid \\
\hline X2.7 & 0,306 & 0.301 & Valid \\
\hline X2.8 & 0,365 & 0.301 & Valid \\
\hline X2.9 & 0,537 & 0.301 & Valid
\end{tabular}

Sumber : Data diolah

Berdasarkan tabel diatas dapat disandingkan pada kolom $r$ hitung (Corrected Item-Total Correlation) dengan $\mathrm{r}$ tabel dapat dilihat dari pengujian validitas bahwa 10 item variabel penelitian, penilaian Disiplin Kerja mempunyai $r$ hitung $<\mathrm{r}$ tabel yaitu pada signifikan 5\% $(\mathrm{a}=0,05)$ dan $\mathrm{n}=41$ diperoleh $\mathrm{r}_{\text {tabel }}=0,301$, Nilai Korelasi terbesar adalah pada pertanyaan 2 dengan nilai $r \quad 0,661$.

Tabel 3

Hasil Uji Validitas Terhadap Variabel Kualitas Kerja (Y) pada Kantor BPN kota Bogor

\begin{tabular}{cccc}
\hline Butir Kuesioner & Nilai r Hitung & Nilai r Tabel & Keterangan \\
\hline Y.1 & 0,422 & 0.301 & Valid \\
\hline Y.2 & 0,630 & 0.301 & Valid \\
\hline Y.3 & 0,449 & 0.301 & Valid \\
\hline Y.4 & 0,547 & 0.301 & Valid \\
\hline Y.5 & 0,504 & 0.301 & Valid \\
\hline Y.6 & 0,691 & 0.301 & Valid \\
\hline Y.7 & 0,458 & 0.301 & Valid \\
\hline Y.8 & 0,445 & 0.301 & Valid \\
\hline Y.9 & 0,432 & 0.301 & Valid \\
\hline Y.10 & 0,630 & 0.301 & Valid
\end{tabular}

Berdasarkan tabel diatas dapat disandingkan pada kolom $\mathrm{r}$ hitung (Corrected Item-Total Correlation) dengan $r$ tabel dapat dilihat dari pengujian validitas bahwa 10 item variabel penelitian penilaian Kualitas Kerja mempunyai $r$ hitung $<r$ tabel yaitu pada signifikan 5\% $(\mathrm{a}=0,05)$ dan $\mathrm{n}=41$ diperoleh $r_{\text {tabel }}=0,301$, Nilai Korelasi terbesar adalah pada pertanyaan 6 dengan nilai $\mathrm{r} 0,691$ 


\section{Tabel 4}

\section{Hasil Uji Reliabilitas dengan program Aplikasi Komputer Terhadap Variabel} Pelatihan (X1) Pada Kantor BPN kota Bogor

\begin{tabular}{ccc}
\multicolumn{3}{c}{ Reliability Statistics } \\
\hline \multicolumn{3}{c}{ Cronbach's } \\
Cronbach's & Alpha Based \\
Alpha & on & Nof Items \\
& Standardized \\
& Items \\
\hline 0.820 & 0.823 & 10 \\
\hline
\end{tabular}

Dengan melihat nilai Cronbach Alpha 0,820 maka dapat disimpulkan bahwa pertanyaan dalam kuesioner Pelatihan adalah Reliabel dan dapat diterima.

\section{Tabel 5}

\section{Hasil Uji Reliabilitas dengan program Aplikasi Komputer Terhadap Variabel} Disiplin Kerja (X2) Pada Kantor BPN kota Bogor

\begin{tabular}{ccc}
\multicolumn{3}{c}{ Reliability Statistics } \\
\hline \multicolumn{3}{c}{ Cronbach's } \\
Cronbach's & Alpha Based \\
Alpha & on & Nof Items \\
& Standardized \\
\multicolumn{3}{c}{ Items } \\
\hline 0.770 & 0.797 & 10 \\
\hline
\end{tabular}

Dengan melihat nilai Cronbach Alpha 0,770 maka dapat disimpulkan bahwa pertanyaan dalam kuesioner Disiplin Kerja adalah Reliabel dan dapat diterima

Tabel 6

Hasil Uji Reliabilitas dengan program Aplikasi Komputer Terhadap Variabel K Kualitas Kerja (Y) Pada Kantor BPN kota Bogor

Reliability Statistics

\begin{tabular}{ccc}
\hline & Cronbach's \\
Cronbach's & Alpha Based & \\
Alpha & on & Nof Items \\
& Standardized \\
& Items \\
\hline 0.833 & 0.830 & 10 \\
\hline
\end{tabular}


Dengan melihat nilai Cronbach Alpha 0,833 maka dapat disimpulkan bahwa pertanyaan dalam kuesioner Kualitas Kerja adalah Reliabel dan dapat diterima.

Dari uji coba yang dilakukan dapat diketahui bahwa hasil Cronbach's Alfa setiap variabel lebih dari standar minimal Cronbach's Alfa yang disyaratkan 0,60. maka variabel pelatihan, disiplin kerja dan kualitas kerja dengan nilai koefisein alfha untuk variabel (X1) Sebesar 0,280, (X2) Sebesar 0,770 dan (Y) Sebesar 0,833.

Persepsi Aperatur Sipil Negara Terhadap Pelatihan (X1)

Sangat Setuju dengan nilai persentase sebesar $41,46 \%$, Setuju dengan nilai persentase sebesar $63,41 \%$,Cukup Setuju dengan nilai persentase sebesar 17,7\%, Tidak Setuju dengan nilai persentase sebesar $0 \%$ dan Sangat Tidak Setuju dengan nilai persentase sebesar $0 \%$ Persepsi Aperatur Sipil Negara Terhadap Disiplin Kerja (X2)

Sangat Setuju dengan nilai persentase sebesar 41,46\%, Setuju dengan nilai persentase sebesar 63,41\%,Cukup Setuju dengan nilai persentase sebesar $36,59 \%$, Tidak Setuju dengan nilai persentase sebesar $0 \%$ dan Sangat Tidak Setuju dengan nilai persentase sebesar 7,32\%

Persepsi Aperatur Sipil Negara Terhadap

Kualitas Kerja (Y)

Sangat Setuju dengan nilai persentase sebesar 39,02\%, Setuju dengan nilai persentase sebesar 60,98\%,Cukup Setuju dengan nilai persentase sebesar 17,07\%, Tidak Setuju dengan nilai persentase sebesar 2,44\% dan Sangat Tidak Setuju dengan nilai persentase sebesar $0 \%$.

\section{Uji Asumsi Klasik}

\section{Uji Normalitas}

Berdasarkan hasil pengujian dengan Aplikasi Komputer, didapatkan nilai signifikan dari masing-masing variabel sebagai berikut :

Variabel Pelatihan dengan nilai signifikan 0,685, Variabel Disiplin Kerja dengan nilai siginfikan 0,732, Variabel Kualitas Kerja dengan nilai Tidak Signifikan 0,887. Dapat disimpulkan bahwa dari 3 variabel tersebut 3 berdistribusi normal dikarnakan nilai signifikannya lebih besar dari 0,05.

\section{Uji Homogenitas}

Berdasarkan hasil pengujian maka dapat diambil kesimpulan bahwa variansi data Y (Kualitas), berdasarkan pengelompokan data X1 (Pelatihan) homogen dikarnakan nilai signifikanya 1,317 , lebih dari 0,05 .

Berdasarkan hasil pengujian maka dapat diambil kesimpulan bahwa variansi data Y (Kualitas), berdasarkan pengelompokan data X2 (Disiplin Kerja) homogen dikarnakan nilai signifikannya 2,096, lebih dari 0,05.

\section{Uji Linearitas}

Berdasarkan hasil Uji Linearitas diketahui bahwa nilai Sig. Deviation From Linearity sebesar 0,883 . Karena nilai 0,883 $>$ 0,05 maka dapat disimpulkan bahwa Ho ditolak dan Ha di terima artinya terdapat hubungan linear variabel pelatihan dengan variabel kualitas.

Berdasarkan hasil Uji Linearitas diketahui bahwa nilai Sig. Deviation From Linearity sebesar 0,997. Karena nilai 0,906 > 0,05 maka dapat disimpulkan bahwa Ho diTolak dan Ha di Terima, artinya terdapat hubungan linear variabel Disiplin Kerja dengan variabel kualitas.

\section{Analisis Hubungan Antara Pelatihan (X1) dan Kualitas Kerja (Y)}

1. Intercept atau Konstanta sebesar 9,432

Berarti apabila variabel bebas $\mathrm{X}_{1}$ (Pelatihan) sama dengan nol, maka besarnya variabel Y (Kinerja) adalah 
9,432. Dengan kata lain, jika variabel bebas $X_{1}$ (Pelatihan) nilai dianggap nol berarti besarnya 9,432 .

2. Arah Hubungan dan Koefisien Regresi

Variabel $\mathrm{X}_{1}$ (Pelatihan) sebesar 0,776 ini berarti berpengaruh terhadap Kualitas Kerja (Y) adalah positif atau setiap kenaikan nilai skor variabel $\mathrm{X}_{1}$ (Pelatihan) sebesar 1 , maka akan meningkatkan nilai skor variabel Y (Kualitas) sebesar 0,776.

3. Koefisien Determinasi

Uji koefisien determinasi bertujuan untuk mengetahui seberapa besar kemampuan variabel independen menjelaskan variabel dependennya yang dilihat melalui $\mathrm{R}$ square. Pada tabel dapat dilihat hasil koefisien determinasi sebesar 0,581 atau $58,1 \%$ memberikan arti bahwa besarnya kontribusi Pelatihan terhadap Kualitas sebesar 58,1\%, sedangkan sisanya $\quad 41,8 \%$ dipengaruhi oleh faktor-faktor lain yang tidak dimasukan dalam peneliti ini.

\section{Analisis Hubungan Antara Disiplin}

\section{Kerja (X2) dan Kualitas Kerja (Y)}

1. Intercept atau Konstanta sebesar 20,036

Berarti apabila variabel bebas $\mathrm{X}_{2}$ (Disiplin Kerja) sama dengan nol, maka besarnya variabel Y (Kualitas) adalah 20,036. Dengan kata lain, jika variabel bebas $\mathrm{X}_{2}$ (Disiplin Kerja) nilai dianggap nol berarti besarnya 20,036.

2. Arah Hubungan dan Koefisien Regresi Variabel $\mathrm{X}_{2}$ (Disiplin Kerja) sebesar 0,527 ini berarti berpengaruh terhadap Kualitas Kerja (Y) adalah positif atau setiap kenaikan nilai skor variabel $\mathrm{X}_{2}$ (Disiplin Kerja) sebesar 1, maka akan meningkatkan nilai skor variabel $\mathrm{Y}$ (Kualitas) sebesar 0, 527.

3. Koefisien Determinasi

Uji koefisien determinasi bertujuan untuk mengetahui seberapa besar kemampuan variabel independen menjelaskan variabel dependennya yang dilihat melalui $\mathrm{R}$ square. Pada table dapat dilihat hasil koefisien determinasi sebesar 0, 284 atau $28,4 \%$ memberikan arti bahwa besarnya kontribusi Disiplin Kerja terhadap Kualitas sebesar 28,4\%, sedangkan sisanya $71.6 \%$ dipengaruhi oleh faktor-faktor lain yang tidak dimasukan dalam peneliti ini.

\section{Analisis Hubungan Antara Pelatihan dan Disiplin Kerja Terhadap Kualitas Kerja}

1. Intercept atau Konstanta sebesar 9,428

Berarti apabila variabel bebas $\mathrm{X}_{1}$ (Pelatihan) dan X2 (Disiplin Kerja) sama dengan nol, maka besarnya variabel Y (Kualitas) adalah 9,428. Dengan kata lain, jika variabel bebas $\mathrm{X}_{1}$ (Pelatihan) dan $\mathrm{X}_{2}$ (Disiplin Kerja) nilai dianggap nol berarti besarnya 9.428 .

2. Arah Hubungan dan Koefisien Regresi

Variabel $\mathrm{X}_{1}$ (Pelatihan) sebesar 0,776 ini berarti berpengaruh terhadap Kualitas Kerja (Y) adalah positif atau setiap kenaikan nilai skor variabel $\mathrm{X}_{1}$ (Pelatihan) sebesar 1, maka akan meningkatkan nilai skor variabel Y (Kualitas) sebesar 0, 776. Variabel $\mathrm{X}_{2}$ (Disiplin Kerja) sebesar 0,000 ini berarti tidak berpengaruh terhadap Kualitas Kerja (Y) adalah positif atau setiap kenaikan nilai skor variabel $\mathrm{X}_{2}$ (Disiplin Kerja) sebesar 1, maka akan meningkatkan nilai 
skor variabel Y (Kualitas) sebesar 0,000 .

3. Koefisien Determinasi

Uji koefisien determinasi bertujuan untuk mengetahui seberapa besar kemampuan variabel independen menjelaskan variabel dependennya yang dilihat melalui $\mathrm{R}$ square. Pada table dapat dilihat hasil koefisien determinasi sebesar 0,284 atau $28,4 \%$ memberikan arti bahwa besarnya kontribusi Disiplin Kerja terhadap Kualitas sebesar 28,4\%, sedangkan sisanya $71,6 \%$ dipengaruhi oleh faktor-faktor lain yang tidak dimasukan dalam peneliti ini.

\section{Uji Hipotesis T}

Berdasarkan pengujian dengan menggunakan Aplikasi Komputer dapat dilihat pada tabel di atas bahwa nilai thitung sebesar 7,350. Karena t-hitung = 7,350 > t-tabel $=2,701$ maka Ha diterima, berarti terdapat pengaruh yang signifikan antara Pelatihan dan Kualitas Kerja.

Berdasarkan pengujian dengan menggunkaan Aplikasi Komputer dapat dilihat pada tabel di atas bahwa nilai $\mathrm{t}$ hitung sebesar 3,935 Karena t-hitung = 3,935 > t-tabel $=2,701$ maka Ha diterima, berarti terdapat pengaruh yang signifikan antara Disiplin Kerja (X2) dan Kualitas Kerja.

\section{Uji Hipotesis F (simultan)}

Karena F hitung $=26,318>\mathrm{F}$ tabel $=3,24$, maka Ho ditolak (Ha diterima), berarti terdapat pengaruh yang signifikan antara Pelatihan dan Disiplin Kerja secara bersama-sama terhadap Kualitas Kerja.

\section{Kesimpulan dan Saran}

\section{Kesimpulan}

Kesimpulan dari hasil dan pembahasan mengenai Pengaruh Pelatihan dan Disiplin Kerja Terhadap Kualitas
Kerja Aperatur Sipil Negara Pada Kantor Badan Pertanahan Nasional Kota Bogor adalah sebagai berikut:

1. Hasil persepsi responden terhadap Pelatihan (X1) diperoleh nilai ratarata 4,22 dengan kategori nilai skor Sangat Baik. Hal tersebut menujukan secara umum respon persepsi terhadap Pelatihan dalam sangat Baik. Pada tabel menujukan nilai $\mathrm{R}$ $=0,762$ terletak pada interval $(0,60-$ 0,799) artinya Kuat. Hubungan regresinya adalah

$\mathrm{Y}=9,432+0,776 \mathrm{X}_{1}$ dan Koefesiensi determinasi sebesar 0,581 atau $58,1 \%$ memberikan arti bahwa besarnya pengaruh Pelatihan terhadap Kualitas kerja sebesar $58,1 \%$, sedangkan sisanya $41,9 \%$ dipengaruhi oleh faktor-faktor lain yang tidak dimasukkan dalam penelitian ini yang tidak disebutkan dalam penelitian ini. Uji Hipotesis dengan nilai t-hitung sebesar 7,350. Karena t-hitung $=7,350>$ t-tabel $=$ 2,701 maka Ha diterima, berarti terdapat pengaruh yang signifikan antara Pelatihan dan Kualitas Kerja.

2. Hasil persepsi responden terhadap Disiplin Kerja ( $\left.\mathrm{X}_{2}\right)$ diperoleh nilai rata-rata 4.20 (pada skala 1-5) dalam interval 3,41 - 4.20 dengan kategori Baik (B). Hal tersebut menujukan secara umum respon terhadap Disiplin Kerja dalam kategori Baik. Pada tabel menunjukan nilai $\mathrm{R}=$ 0,533 terletak pada interval $(0,40$ 0,599), hal ini menunjukan bahwa hubungan antara variabel $\mathrm{X}_{2}$ (Persepsi Terhadap Disiplin Kerja) dan Y (Persepsi Terhadap Kualitas) adalah Sedang. Hubungan regresinya adalah $\mathrm{Y}=20,036+0,527 \mathrm{X}_{2}$ Koefesiensi determinasi sebesar 
0,284 atau $28,4 \%$ memberikan arti bahwa besarnya kontribusi Disiplin Kerja terhadap Kualitas sebesar $28,4 \%$, sedangkan sisanya $28,4 \%$ dipengaruhi oleh faktor-faktor lain yang tidak dimasukan dalam peneliti ini. Uji Hipotesis dengan nilai thitung sebesar 3,935 Karena t-hitung = 3,935 > t-tabel = 2,701 maka Ha diterima, berarti terdapat pengaruh yang signifikan antara Disiplin Kerja (X2) dan Kualitas Kerja. Dari tabel persepsi reponden terhadap Kualitas Kerja diperoleh nilai rata-rata sebesar 4,22 dengan kategori nilai Sangat Baik. Hal tersebut menunjukan bahwa secara umum respon tehadap Kualitas Kerja Baik.

3. Analisis hubungan Pelatihan dan Disiplin Kerja secara bersamaan terhadap Kualitas Kerja berdasarkan tabel menunjukan $\mathrm{R}=0,533$ terletak pada interval $(0,40-0,599)$, hal ini menunjukan bahwa hubungan antara variabel $\mathrm{X}_{1}$ (Pelatihan) dan variabel $\mathrm{X}_{2}$ (Disiplin Kerja) secara bersamasama terhadap Y (Kualitas) adalah Sedang dan positif. Persamaan regresinya $\mathrm{Y}=9,428+0,776 \mathrm{X} 1+$ $0,000 \mathrm{X} 2$ Determinasi 0,284 atau (28,4\%). Memberikan arti bahwa besarnya kontribusi Pelatihan dan Disiplin Kerja secara bersama-sama terhadap kualitas kerja sebesar $28,4 \%$, sedangkan sisanya $71,6 \%$ dipengaruhi oleh faktor-faktor lain yang tidak dimasukkan dalam penelitian ini. Karena $\mathrm{F}$ hitung = 26,318> F tabel = 3,24, maka Ho ditolak (Ha diterima), berarti terdapat pengaruh signifikan antara pelatihan dan disiplin kerja terhadap kualitas kerja .

\section{Saran}

Saran yang dapat diberikan dari pembahasan mengenai Pengaruh Pelatihan dan Disiplin Kerja Terhadap Kualitas Kerja Aperatur Sipil Negara Pada Kantor Badan Pertanahan Nasional Kota Bogor sebagai berikut:

1. Berdasarkan hasil penelitian bahwa terdapat pengaruh yang signifikan antara Pelatihan terhadap kualitas kerja dengan tingkat hubungan ialah Kuat. Hal ini berarti harus dipertahankan dalam hal Pelatihan terhadap Aperatur Sipil Negara Kantor BPN.

2. Berdasarkan hasil penelitian bahwa terdapat pengaruh yang signifikan antara Disiplin Kerja terhadap kualitas kerja dengan tingkat hubungan ialah sedang. Diharapkan adanya peningkatan dalam disiplin kerja kepada Aperatur Sipil Negara.

3. Berdasarkan hasil penelitian bahwa terdapat pengaruh yang signifikan secara simultan (serempak) antara Pelatihan dan Disiplin Kerja terhadap kualitas kerja, dengan tingkat hubungan ialah sangat kuat. Dengan ini diharapkan dengan mempertahankan yang telah ada dan meningkatkan yang diperlukan, segala Pelatihan dan disiplin kerja agar dapat berjalan dengan baik dan dapat memberikan hasil kinerja yang lebih baik

\section{Daftar Pustaka}

Arikunto, S. (2013). Prosedur Penelitian (cetakan ke 15). jakarta: Rineka Cipta.

Hamali, A. Y. (2016). Pemahaman Sumber Daya Manusia (Cetakan pertama). Jakarta: CAPS. 
Handoko, T. H. (2015a). Manajemen (Cetakan Kedua). Yogyakarta: BPFE-YOGYAKARTA.

Handoko, T. H. (2015b). Manajemen Personalia dan Sumber Daya Manusia (Edisi Kedua). Yogyakarta: BPFEYOGYAKARTA.

Hasibuan, M. S. P. (2017). Manajemen Sumber Daya Manusia (Edisi Revisi). Jakarta: PT. Bumi Aksara.

Indriyani, S. (2015). Pengaruh Pelatihan Kerja dan Disiplin Kerja Terhadap Produktivitas Kerja Karyawan pada PT. PARADISE ISLAND FURNITURE (Other, Fakultas Ekonomi). Diambil dari https://eprints.uny.ac.id/29859/

Karyoto. (2015). Dasar-Dasar Manajemen (Edisi Pertama). Yogyakarta: ANDI Yogyakarta.

Kementerian Agraria dan Tata Ruang/Badan Pertanahan Nasional $>$ Tentang Kami > Sekilas ATR/BPN. (t.t.). Diambil 7 Mei 2019, dari https://www.atrbpn.go.id/TentangKami/Sekilas-ATR-BPN

Lagale, D. G., Mekkel, P. A., \& Sepang, J. L. (2014). Pelatihan, Dsiplin Kerja dan Kualitas Kerja Terhadap Prestasi Kerja Pada PT. PLN (PERSERO) AREA MANADO. Jurnal EMBA: Jurnal Riset Ekonomi, Manajemen, Bisnis Dan Akuntansi, 2(2). Diambil dari https://ejournal.unsrat.ac.id/index.p hp/emba/article/view/4440

Mangkunegara, A.A, A. P. (2015). Manajemen Sumber Daya Manusia Perusahaan. Bandung: PT. Remaja Rosdakarya.

Melati, R., Soepeno, \& Firdaus, M. A. (2014). Pengaruh Disiplin Dan
Kepuasan Kerja Terhadap Prestasi Kerja Karyawan Pada Pt. Adi Citra Megah. Inovator, 3(1). https://doi.org/10.32832/inovator.v3 i1.665

Notoatmojo, S. (1998). Pengembangan Sumber Daya Manusia (Revisi). Jakarta: PT. Rineka Cipta.

Safitri, E. (2013). Pengaruh Pelatihan dan Disiplin Kerja Terhadap Kinerja Karyawan. Jurnal Ilmu Manajemen (JIM), 1(4). Diambil dari https://jurnalmahasiswa.unesa.ac.id/ index.php/jim/article/view/6262

Sahangggamu, P. M., \& Mandey, S. L. (2015). Pengaruh Pelatihan Kerja, Motivasi, Dan Disiplin Kerja Terhadap Kinerja Karyawan Pada Pt. Bank Perkreditan Rakyat Dana Raya. Jurnal EMBA: Jurnal Riset Ekonomi, Manajemen, Bisnis Dan Akuntansi, 2(4). Diambil dari https://ejournal.unsrat.ac.id/index.p hp/emba/article/view/6359

Sedarmayati. (2010). Sumber Daya Manusia dan Produktivitas kerja. Bandung: CV Mandar Maju.

Siagian, S. (2015). Manajemen Sumber Daya Manusia (Edisi Pertama, Cetakan kesembilan). Jakarta: PT. Bumi Aksara.

Sinambala, L. P. (2017). Manajamen Sumber Daya Manusia (Cetakan kedua). Jakarta: Bumi Aksara.

Sugiyono. (2011). Metode Penelitian Kualitatif, Kuantitatif dan $R \& D$. Bandung: AFABETA.

Sujarweni, W. (2015). Metodologi Penelitian Bisnis dan Ekonomi. Yogyakarta: PT. Pustaka Baru.

Sutrisno, E. (2009). Manajemen Sumber Daya Manusia (Edisi Pertama, Cetakan kesembilan). Jakarta: Kencana. 
Syawal, F. (t.t.). Pengaruh Pelatihan dan Disiplin Kerja Terhadap Prestsi Kerja Karyawan pada PT PLN (PERSERO) AREA KENDARI. 120.

Undang-Undang Aparatur Sipil Negara. (2014). Dalam Wikipedia bahasa Indonesia, ensiklopedia bebas. Diambil dari https://id.wikipedia.org/w/index.php ?title=UndangUndang_Aparatur_Sipil_Negara\&ol $\operatorname{did}=7881119$ 